\title{
The Effect of Tilt Angle of Axial Fan Blades on Air Flow Distribution in the Cabinet Dryer: Simulation Study Using Computational Fluid Dynamics
}

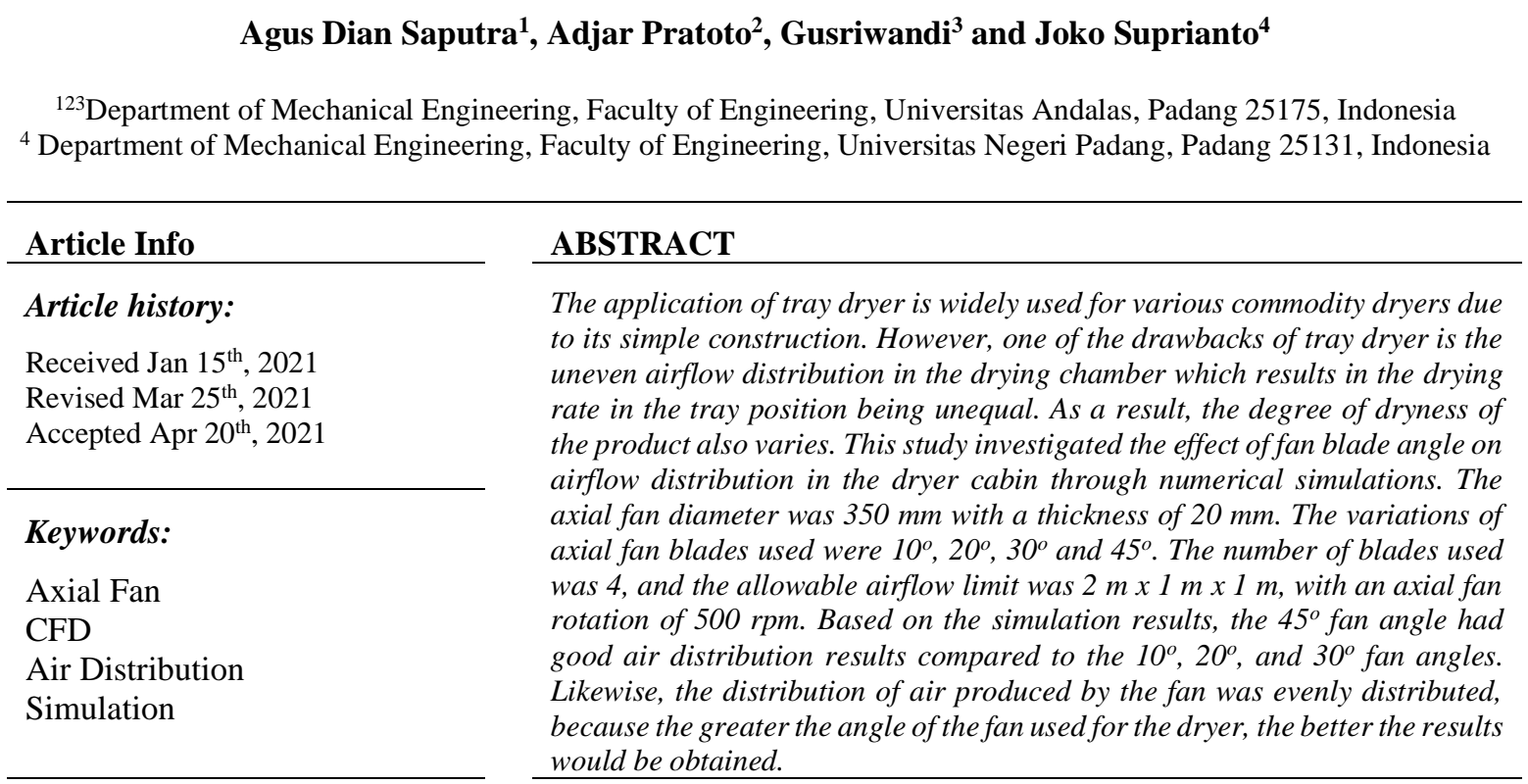

\section{Corresponding Author:}

Agus Dian Saputra,

Department of Mechanical Engineering, Faculty of Engineering, Universitas Andalas

Limau Manis, Kec. Pauh, Padang 25175, Sumatera Barat, Indonesia

Email: agus.galaxy.s@gmail.com

\section{INTRODUCTION}

Drying is the process of removing moisture from a material [1]. The drying process applies when the material loses partial or complete its water content [2]. In the drying process, a heat transfer process occurs from a material used as a dryer medium to material to be dried. At high humidity, the rate of water evaporation is slower than drying at low humidity [3]. There are several methods used in the drying process. One of them is the traditional method by utilizing solar power directly as a drying medium which known as conventional drying [4]. Another drying method is by using fan media by utilizing the fluid flow of hot air which will be conveyed to the material to be dried, and this method is usually known as artificial drying (mechanical) [5]. This method is more profitable than natural drying, because it does not require solar energy as a heating medium in the dryer so that it can be used at any time, day or night.

In a mechanical dryer, the fan is used as a spreading heat medium, so it has a different function from the compressor. Fan work can produce fluid with a high flow rate but low working pressure, while the compressor produces a low flow rate but high working pressure [6]. There are two types of fans that are usually applied in the drying process, namely axial fans and centrifugal fans. Centrifugal fans are able to replicate the dominant characteristics of airflow [7].

Axial fans can produce high airflow rates with low pressure and own a simple construction [8]. The fan is usually combined with a heater, which is used as a heating medium so that the airflow can be generated. The fan performing the process is influenced by speed which creates airflow with a high flow rate but low pressure [9]. Axial fan will create airflow in parallel to its axis and produce air out in the same direction. The axial fan working system utilizes the lift force generated by the fan blade so that it can flow fluid. However, in the axial fan experiment, it is very difficult to determine the distribution system in the drying process, the velocity of the air flow and the pressure present during the drying process. The use of Computational Fluid Dynamics (CFD) software could help to determine the value of the dispersion flow velocity in the axial fan, the 
temperature that can be delivered by the axial fan evenly in the drying process and the pressure generated by the axial fan.

\section{METHODS}

The Computational Fluid Dynamics (CFD) method used research variables by varying the fan angle that was used as a comparison in this simulation with angles of $10^{\circ}, 20^{\circ}, 30^{\circ}$ and $45^{\circ}$. If the slope of the fan angle is small, the fluid flow movement will be small too, and if the slope of the fan angle is greater, the movement of fluid flow in the fan will also be greater [10]. The type of fan used as a reference in the design used for simulation is axial fan type which has the advantage of a centrifugal fan, which is to produce a high airflow rate but low pressure [11]. With the same dimensions of $350 \mathrm{~mm}$ and the number of fan blades 4 , then testing will be carried out using computer simulations. The initial stage begins with the constraction of a fan model and then analyzed using computer simulations. To get the results of the spread of air flow from each variation of the fan used, and observe the size of the air flow that is delivered. The fan model was created using Solidwork 2019 software and for computer simulation, using Ansys Student 2019 software.

\subsection{Making Geometry System in 3-Dimensional Field}

\subsubsection{Preprocessing}

Making the geometry of the axial fan 3D plane system, as the initial step the researher first prepared the axial fan design which was carried out by using Solidwork 2019 Software. The design dimensions used for axial fans were $350 \mathrm{~mm}$ and the thickness was $20 \mathrm{~mm}$. The CFD simulation was carried out using the Ansys Student 2019 Software with Transient conditions to determine and design so that heat and air flow delivered by the axial fan can spread evenly. Making a CAD (Computer Aided Design) model and making a mesh that suits your needs [12]. In the CFD simulation stages, preprocessing is carried out.

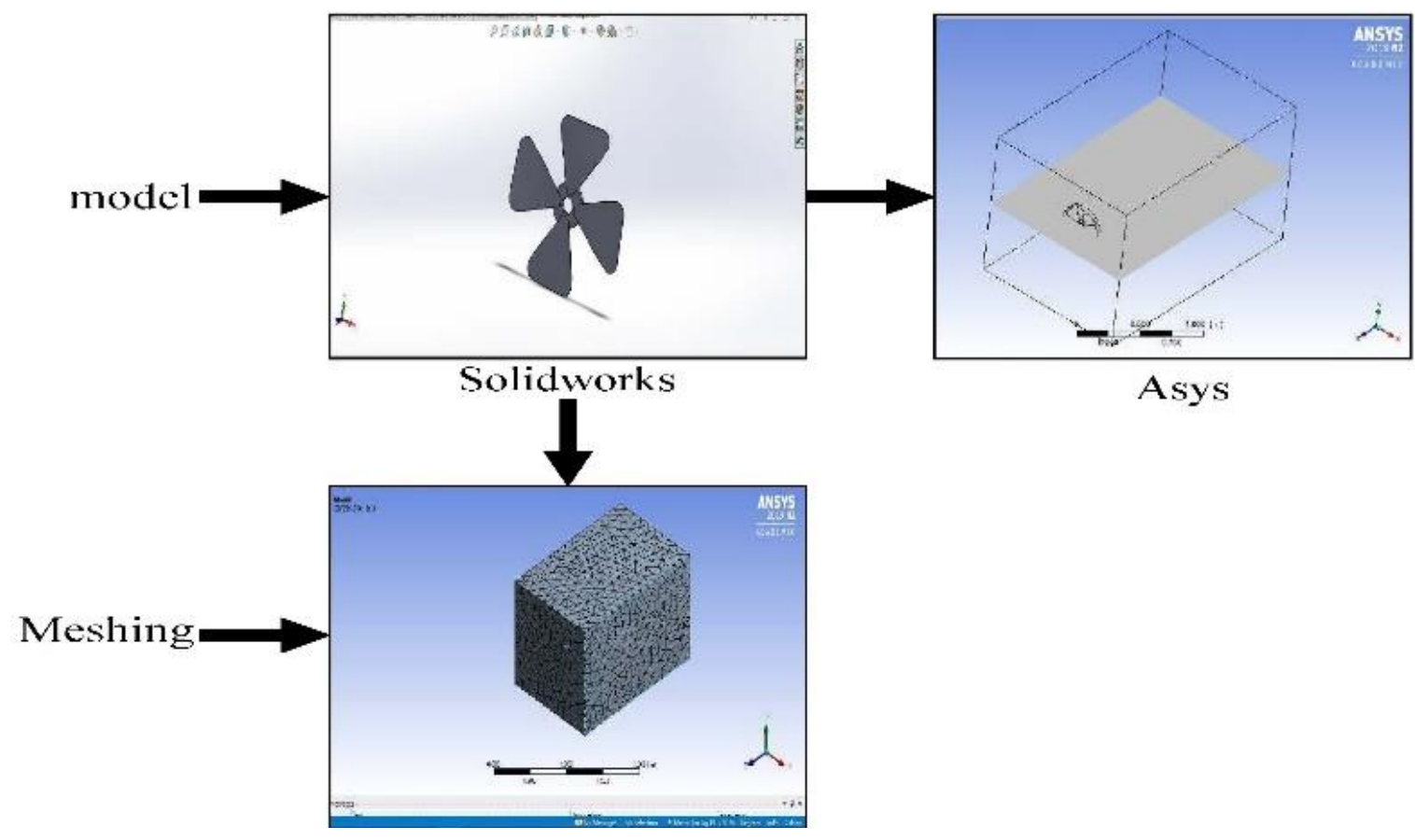

Figure 1 : Preprocessing

\subsubsection{Solving}

Solvers are the core program for finding CFD solutions, to calculate the conditions that are applied at the time of preprocessing. At this stage there are parameters or conditions that are regulated in relation to the determination of the boundary conditions when performing the simulation, such as: general, models, materials, cell Zone conditions, boundary conditions, mesh interface, reference value, and solution method. The solving stages are determined in Figure 2. 
1. General

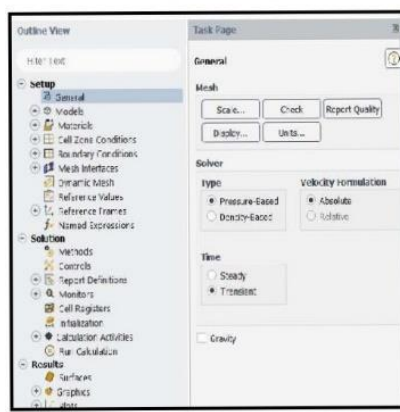

6. Mesh Interface

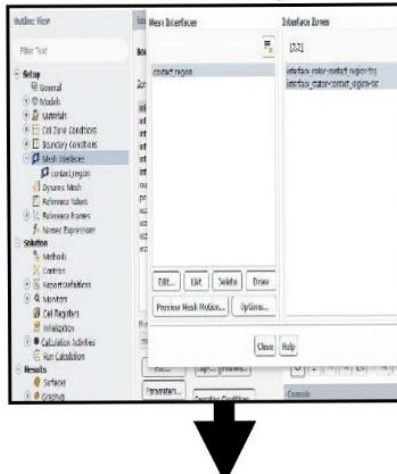

7. Reference Value

\section{Models}

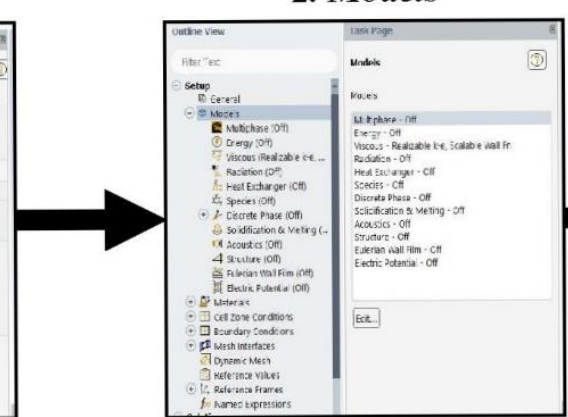

3. Materials

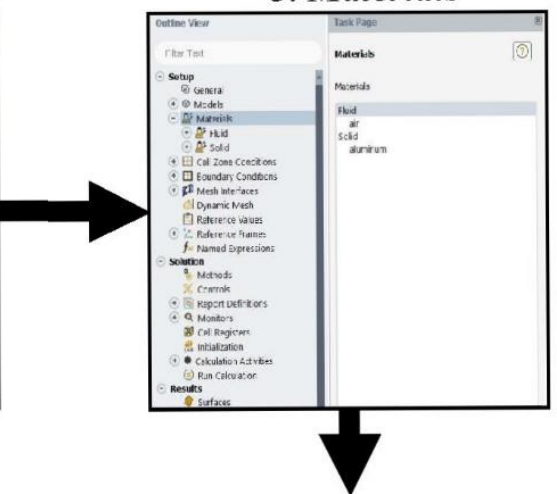

\section{Boundary Conditions}

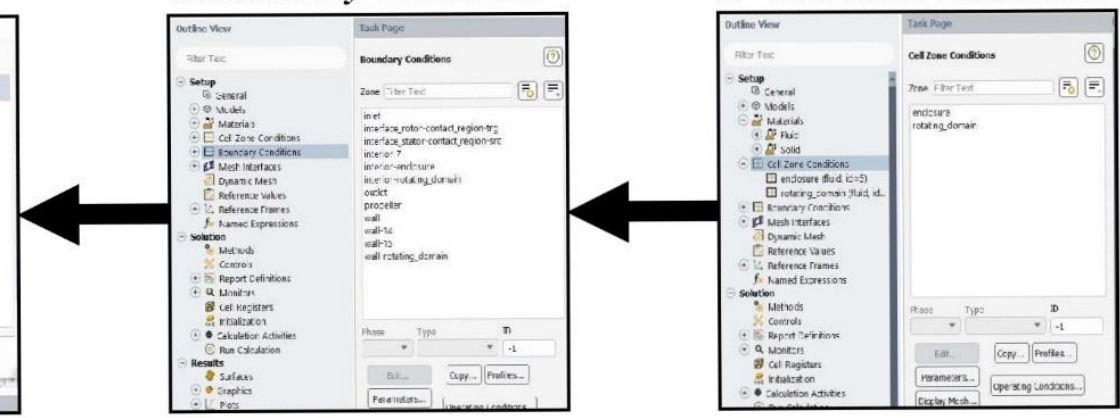

4. Cell Zone Conditions

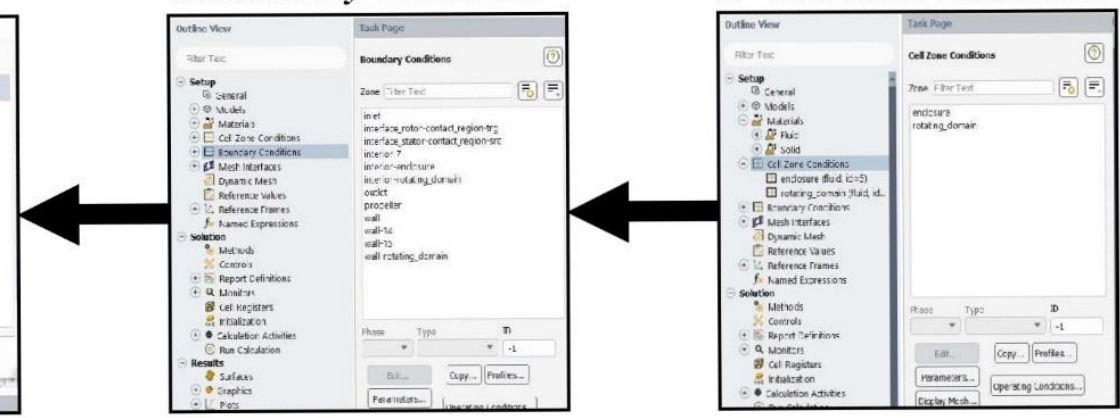

8. Solution Methods

9. Solution Initialization
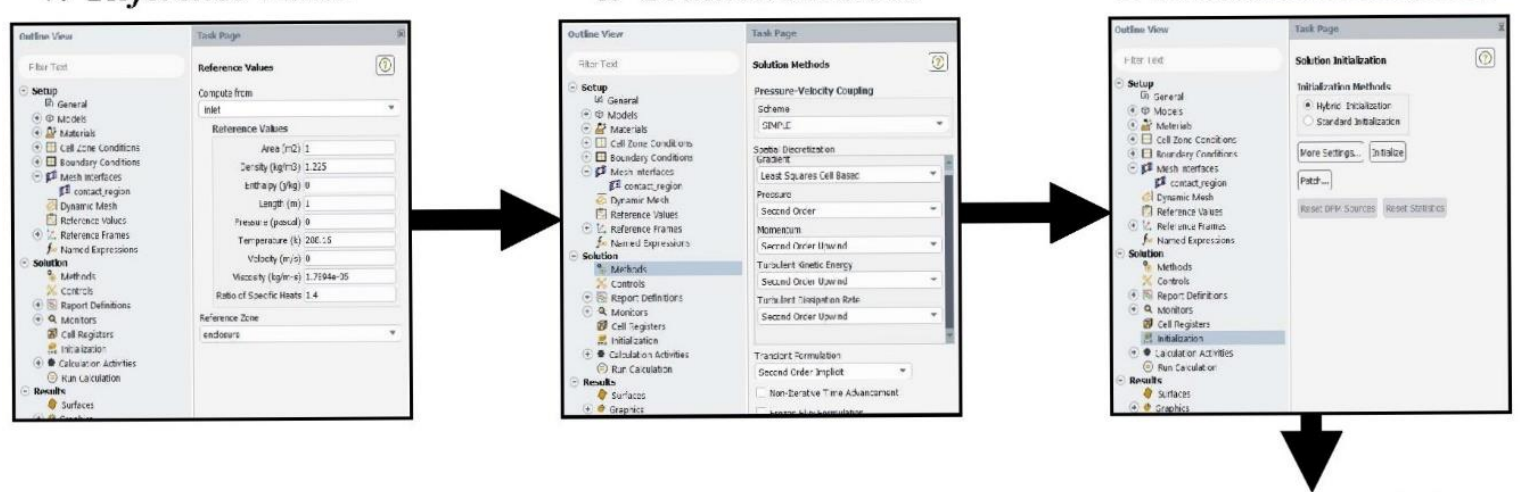

10. Run Calculation

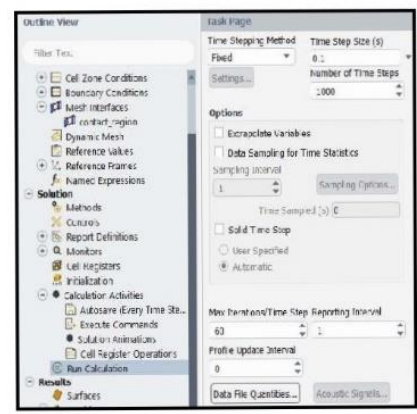

Figure 2 : Determining the conditions for performing the simulation

The stages of selecting the limits of the CFD solution seeker program for simulations apply several methods. The first general in simulating the dialed pressure-base for velocity formulation is used in absolute form. Selection of models was to see how the fluid flow affects the e-realizable, scalable with two equations, 
namely the momentum equation and the continuity equation. In using the Material used, it can be set on the task page material. Cell Zone Conditions is used for the selection of system conditions in the simulation. Boundary Conditions provide conditions for the Inlet and Wall system. Mesh Interface is used to provide mesh surfaces that are in contact with each other. Reference Value is used in determining the value and where the calculation starts from. Solution Methods used SIMPLE simulation scheme. The solution initialization used is Hybrid Initialization. Run Calculation in this process is calculated until it converges.

\subsubsection{Postprocessing}

Post processing is the final step in CFD analysis. It is done in order to organize and interpret the simulation results data, the data can be in the form of images, curves, and animations. From the simulation results obtained the pattern of the air distribution on the axial fan.

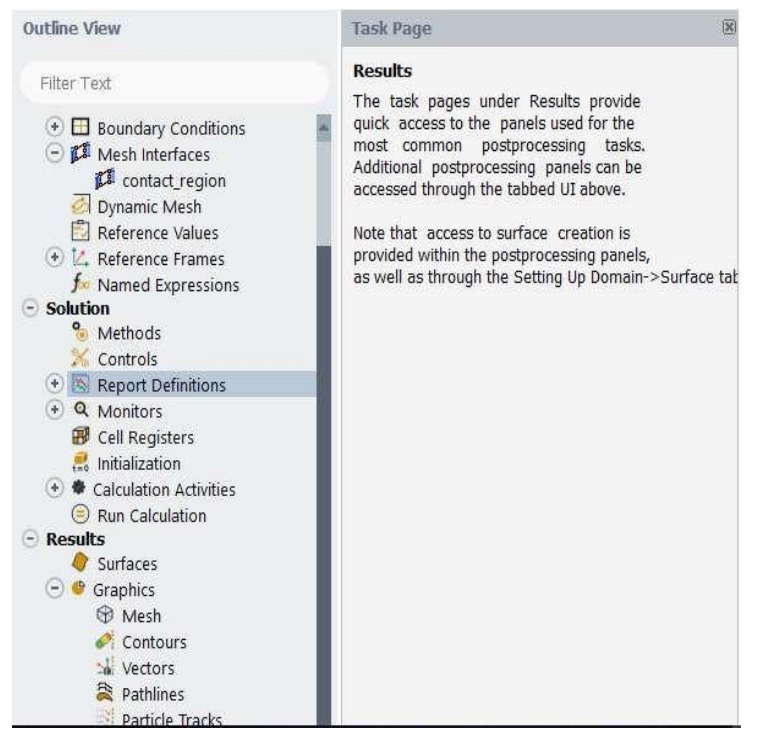

Figure 3 : Result Toolbar

\subsection{Computational Fluid Dynamic (CFD)}

Computational Computational Fluid Dynamic or commonly known as (CFD) is a technique used to analyze systems involving the fluid flow, heat transfer or chemical reactions using computer simulations [13]. In addition, this analysis was apparently useful to simplify the process of figuring out the numerical results with volume control as an element of the equations integration, which consisted of equations of mass, momentum, and energy balance [14]. And the appropriate selection of Fan blade profile to improve the efficiency of CFD fan flow simulation [15]. However, there were also some shortcomings in the Computational Fluid Dynamics (CFD) Software because the results obtained through the simulation were caused by classiness of numerical data input, error in boundary conditions, and limited capabilities of computational tools. By using Computational Fluid Dynamics (CFD) software, it helped to find out the value of the dispersion flow velocity in the axial fan, the temperature distributed by the axial fan evenly in the drying process and the resulting pressure on the axial fan. During the process of designing the axial fan, Solidwork Software and Ansys Student 2019 were used [16]. to obtain these data such as the continuity equation (1), the momentum equation (2-4), and the energy equation (5).

$$
\begin{aligned}
& \frac{\partial}{\partial t}\left(\gamma \alpha_{q} \rho_{q}\right)+\nabla \cdot\left(\gamma \alpha_{q} \rho_{q} \vec{V}_{q}\right)=\gamma \sum_{p=1}^{n}\left(\dot{m}_{p q}-\dot{m}_{q p}\right)+\gamma S_{q} \\
& \frac{\partial}{\partial t}\left(\gamma \alpha_{q} \rho_{q} \vec{V}_{q}\right)+\nabla \cdot\left(\gamma \alpha_{q} \rho_{q} \vec{V}_{q} \vec{V}_{q}\right)=-\gamma \alpha_{q} \nabla p+\nabla \cdot(\gamma \overline{\bar{\tau}} q)+\gamma \alpha_{q} \rho_{q} \vec{g} . \\
& +\gamma \sum_{p=1}^{n}\left(\vec{R}_{p q} \dot{m}_{p q} \vec{V}_{p q}-\dot{m}_{q p} \vec{V}_{p q}\right) \\
& +\gamma\left(\vec{F}_{q}+\vec{F}_{l i f t, q}+\vec{F}_{v m, q}\right) \\
& \frac{\partial}{\partial t}\left(\gamma \alpha_{q} \rho_{q} h_{q}\right)+\nabla \cdot\left(\gamma \alpha_{q} \rho_{q} \vec{V}_{q} h_{q}\right)=-\gamma \alpha_{q} \frac{\partial}{\partial t}+\gamma \overline{\bar{\tau}} q: \nabla \vec{V}_{q}-\nabla\left(\gamma \vec{q}_{q}\right)+\gamma S_{q}
\end{aligned}
$$




\section{RESULTS AND DISSCUSSION}

CFD simulation testing produced hot air flow rates on the axial fans with a total number of 4 blades with angles variations $10^{\circ}, 20^{\circ}, 30$ and $45^{\circ}$. Additionally, the air speed and temperature, was assumed to be similar with the angle variation $500 \mathrm{rpm}$ with a dimension of $350 \mathrm{~mm}$ fan.
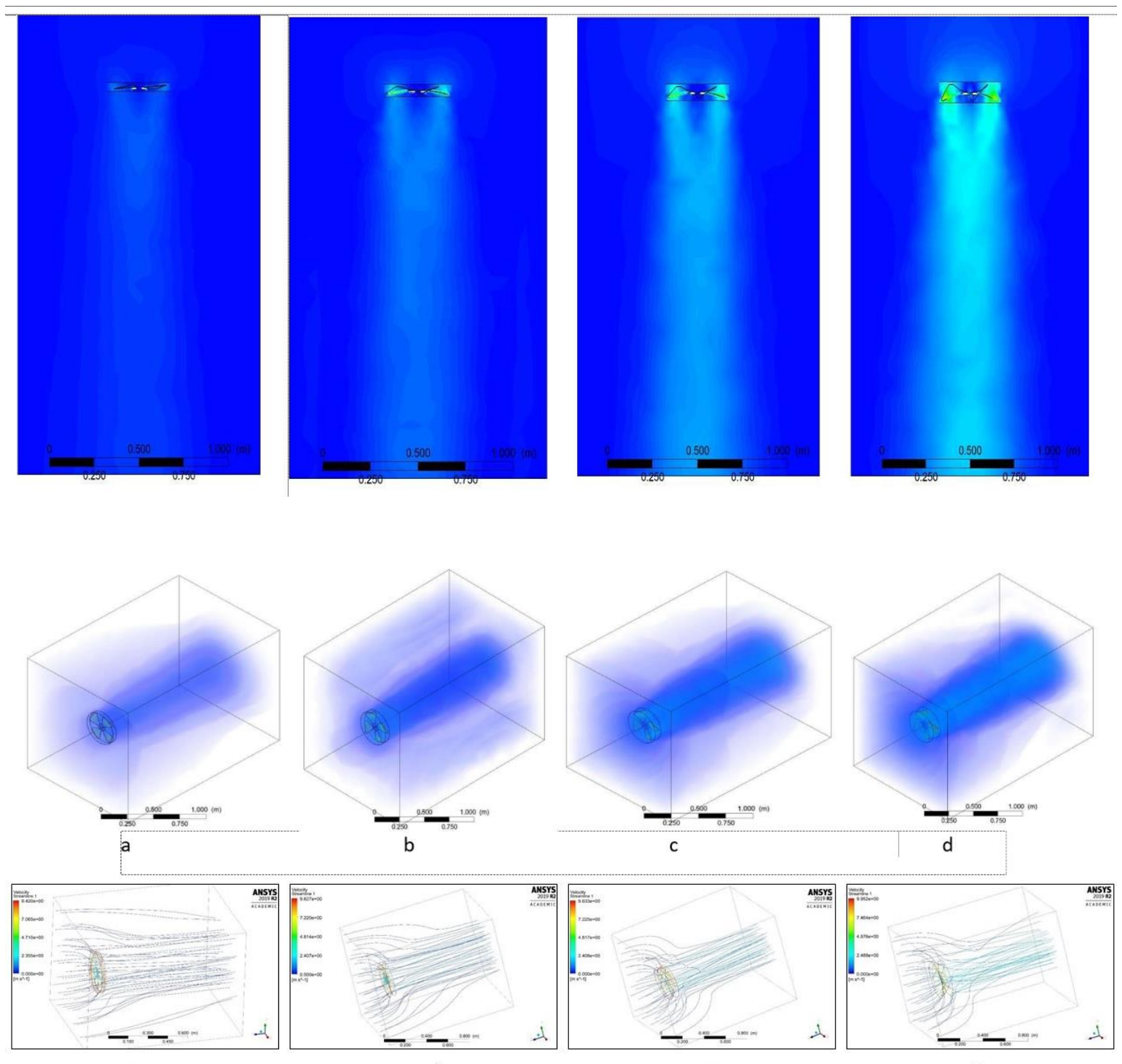

Figure 4 : Proportionally distribution of fluid flow

(a) $10^{\circ}$, (b)

(b) $20^{\circ}$,

(c) $30^{\circ}$ and (d) $45^{\circ}$

Based on the results of the simulation, it was concluded that the bigger the angle used, the better the airflow will be. As a matter of fact, the smallest $10^{\circ}$ angle distribution of the air flow was not categorized as large and the air spread was only in a small scale. This phenomenon resulted in the air flow entering the inlet to the fan that cannot be delivered maximally. In addition, the $20^{\circ}$ angle also had a flow distribution that is almost the same as the $10^{\circ}$ angle, but the air flow is almost flat. The angles in which the flow is most evenly distributed are the angles of $30^{\circ}$ and $45^{\circ}$. At an angle of 300, the air flow delivered by the fan began to increase which resulted in a well-even flow of air, then at 45 o the air flow distributed has spread evenly in every corner of the room which showed that the distribution in the room was evenly distributed. It was assumed that a quality spread that would be used in the manufacture of the drying cabin is using a fan that has an angle of $45 \mathrm{o}$, having an even level of distribution in the fluid flow delivered by the axial fan, and the drying process produced was much faster and evenly distributed during the further drying process. 


\section{CONCLUSION}

Based on the testing result on CFD, it can be concluded that the dryer used in the rack type had an axial fan which consisted of 4 angular comparisons that allowed air distribution to dry a material that containing water and a heat transfer process occurs from the drying medium. From the 4 angles, the ratio of $10^{\circ}, 20^{\circ}, 30^{\circ}$ and $45^{\circ}$ axial fans with a diameter of $350 \mathrm{~mm}$ and a thickness of $20 \mathrm{~mm}$ was assumed to have the same speed of $500 \mathrm{rpm}$. Stating that the greater the angle used in the manufacture of the axial fan, the resulting air flow is very important in the spread of air in the drying process. Meanwhile, the resulting small angular air distribution is very uneven because of the small tilt angle. In fact, the tilt from the fan angle greatly affected the length of time required to evenly distribute the airflow during the drying process. Therefore, if the air flow is distributed in a large scale, the results obtained will also quickly flatten the air streams. However, if the angle of the fan is small, the drying time will also take time.

\section{REFERENCES}

[1] M. Riswandi, Abdul Makhsud, "Unjuk kerja pengering kakao tipe tray dryer dengan mengalirkan udara panas secara zik-zak,” J. Tek. Mesin, no. 2.3, pp. 50-56, 2021.

[2] R. Hasibuan, "Mekanisme peneringan," pp. 1-8, 2004.

[3] M. Taufik, "Pengaruh temperatur terhadap laju pengeringan jagung pada pengering konvensional dan fluidized bed," Universitas Sebelas Maret, 2004.

[4] R. I. M. Azridjal Aziz, Ahmad Surya, "Pengujian pengering tenaga surya tipe pada kondisi berbeda," J. Sains dan Teknol. 18, vol. 18, no. September, pp. 82-90, 2019.

[5] M. Martinello and S. Giner, "Simulation of natural air drying of maize in a typical location of argentina: influence of air heating through the fan," Biosyst. Eng., vol. 107, no. 1, pp. 36-45, 2010, doi: 10.1016/j.biosystemseng.2010.06.010.

[6] D. A. Wulandari et al., "Pengaruh sudut bilah pada performa kipas menggunakan metode komputasi," J. Konversi Energi dan Manufaktur UNJ, vol. 46, no. April, pp. 77-82, 2014.

[7] B. P. Vidiyanto, W. Aryadi, A. M. Khoiron, and S. Anis, "Pengaruh penggunaan fan dan debit fluida terhadap efisiensi kerja atmospheric water generator," J. Rekayasa Mesin, vol. 10, no. 2, pp. 105-112, 2019, doi: 10.21776/ub.jrm.2019.010.02.1.

[8] A. S. Tanjung, "Studi eksperimen pengaruh blade setting experimental study the effects of blade setting angle $30^{\circ}$ and $60^{\circ}$ with flat plate profile in working characteristic curve of axial fan $120 \mathrm{~mm}$," Instutut Teknologi Sepuluh Nopomber, 2015.

[9] F. Babich, M. Cook, D. Loveday, R. Rawal, and Y. Shukla, "Transient three-dimensional CFD modelling of ceiling fans," Build. Environ., vol. 123, pp. 37-49, 2017, doi: 10.1016/j.buildenv.2017.06.039.

[10] S. Hyun, M. Hun, Y. Kim, and M. Choi, "Effects of freestream on piezoelectric fan performance," j. fluids struct., vol. 87, pp. 302-318, 2019, doi: 10.1016/j.jfluidstructs.2019.04.007.

[11] Prasetiyadi, "Modifikasi putaran fan untuk meningkatkan efisiensi pemakaian listrik," Tek. Lingkung., vol. 9-16, no. juli, 2006.

[12] G. R. Supit, H. Luntungan, and B. Maluegha, "Simulasi numerik aliran fluida dalam penstock dengan menggunakan computational fluid dynamics (CFD)," J. online poros Tek. mesin, vol. 3, no. 10, pp. 77-88, 2014.

[13] Gusriwandi, "Kajian cfd perbandingan kinerja tiga buah model runner turbin francis," vol. 21, no. 2, pp. 77-84, 2014.

[14] W. M. Versteeg, Henk Kaarle, An introduction to computational fluid dynamics: the finite volume method. Pearson education, 2007.

[15] D. C. Panigrahi and D. P. Mishra, "CFD simulations for the selection of an appropriate blade profile for improving energy efficiency in axial flow mine ventilation fans,” J. Sustain. Min., vol. 13, no. 1, pp. 15-21, 2014, doi: 10.7424/jsm140104.

[16] L. Carlos, V. Guedes, and S. Filipe, "Science direct sciencedirect computational behavioral study study and and computational fluid fluid dynamics dynamics (CFD): behavioral optimization of of the the blades blades number number of of a a radial radial fan fan optimization," Procedia Manuf., vol. 38, no. Faim 2019, pp. 1324-1329, 2020, doi: 10.1016/j.promfg.2020.01.157. 